\title{
Green Economy Development in Vietnam and the Involvement of Enterprises
}

\author{
Ho Thuy Ngoc ${ }^{1}$, Nguyen Tu Anh ${ }^{2}$ \\ ${ }^{1}$ International Education Faculty, Foreign Trade University, Hanoi, Vietnam \\ ${ }^{2}$ Central Institute for Economic Management (CIEM), Vietnam's Ministry of Planning and Investment, Hanoi, \\ Vietnam \\ Email: "ngocht@ftu.edu.vn,nguyentuanh@mpi.gov.vn
}

Received 18 February 2016; accepted 13 March 2016; published 16 March 2016

Copyright (C) 2016 by authors and Scientific Research Publishing Inc.

This work is licensed under the Creative Commons Attribution International License (CC BY). http://creativecommons.org/licenses/by/4.0/ c) (i) Open Access

\begin{abstract}
Vietnam has become increasingly integrated into the global economy since its accession to the WTO in 2007, which is not only beneficial, but also detrimental. Membership was almost immediately followed by the 2008 global financial crisis which, along with Europe's escalating public debt, dramatically slowed Vietnam's, at that time, rapidly developing economy. To mitigate the persisting effects of that economic shock and facilitate growth sufficient to the needs of its citizens, Vietnam is obligated to reevaluate the sustainability of its "brown economy" and develop strategies toward the adoption of a "green economy" growth model. Vietnam is fortunately located in a region that has been experiencing dramatic economic development and with its neighboring countries, many advantageous social and legal conditions for the development of a green economy. Yet, Vietnam's economy persists in being driven by a brown growth model which is characterized by reliance on raw materials production, the consumption of unsustainable quantities of fossil fuels and natural resources and burgeoning environmental pollution. This paper provides a nation-level analysis of green technology development in Vietnam by using the data from the National Office of Intellectual Property to analyze the extent to which green technology constitutes technology use in Vietnam. Vietnamese enterprises were interviewed to gain insight and data regarding the development and renovation of green technology. Given this situation, an assumption is made that initial growth in greening the economy is primarily driven by enterprises. Greening economy can start from technology renovation and it was hypothesized that such renovation would have been due to both knowledge-based labor and outside support. It was also hypothesized that green economy can be pushed under the outside pressure on Vietnamese enterprises. This paper was designed to test these hypotheses.
\end{abstract}

\section{Keywords}

Green Economy, Technology Renovation, Green Renovation

*Corresponding author. 


\section{Introduction}

Green economic development has been a global trend for sustainable growth in developing countries. Vietnam is no exception. The "Agenda 21" action plan on sustainable development identified that the country's official task was to change its growth model and restructure the economy towards sustainable development. Vietnam is in the most dynamic economic region in the world and has favorable conditions for greening the economy. However, it is also admitted that a green economy has not developed in Vietnam. Vietnam's economy persists in being driven by a brown growth model which is characterized by reliance on raw materials production, the consumption of unsustainable quantities of fossil fuels and natural resources and burgeoning environmental pollution. In fact, the dominant forces in the economy are unsustainable energy-intensive highly polluting raw materials processing industries, the antithesis of green technology.

A large body of academic research studies green economic concepts from various perspectives, the needs and the requirements for green economic development in both developed and developing countries and the common view is that the green economy is one in which the contribution of enterprises plays a dominant role. Many empirical studies in the literature to date examine the strategies adopted by a variety of businesses, which have helped to fuel green development in economic sectors such as energy, technology, agriculture, etc. and in many countries, including Vietnam.

Vietnam's economy is in the process of developing and opening up to world markets. Clearly, new strategies are required. Given the importance of the greening transition in the process, there have been a lot of studies focusing on the policy framework for the green economy development in Vietnam [1]-[4]. There are a few researches at firm-based level on the involvement of enterprises on green economic development in Vietnam. Our study attempts to fill in this gap in the literature by the assumption that initial growth in greening the economy is primarily driven by enterprises. Greening economy can start from technology renovation and it was hypothesized that such renovation would have been due to both knowledge-based labor and outside support. It was also hypothesized that green economy can be pushed under the outside pressure on Vietnamese enterprises. This paper was designed to test these hypotheses and aimed at addressing obstacles to the contribution of enterprises to the green economy development in Vietnam.

\section{Literature on Green Economy and Hypotheses}

\subsection{Green Economy}

The topic of the green economy has been debated since the 1970s, and especially since October 2008 when UNEP together with the developed economies implemented the idea of the green economy. It is possible to broadly categorize research reports about the green economy into two groups. The first group specializes in basic concepts, principles and views of green economic development such as Holger Rogall (2011), Nachhaltige Ökonomie-Ökonomische Theorie und Praxis einer nachhaltigen Entwicklung; Earthsummit 2012, Principles for the green economy: a collection of principles for the green economy in the context of sustainable development and poverty eradication; OECD (2011) Towards green growth: A summary for policy makers, Paris; UNEP (2011), Towards a green economy: Pathways to sustainable development and poverty eradication, Nairobi; UN (2012), Working towards a balanced and inclusive green economy: A United Nations System-wide perspective [5]-[9].

The second group analyzes specific situations and development strategies in some countries and regions such as UNESCO (2011), from green economies to green societies, Paris; UNEP (2010), Green economy-Developing countries success stories, Nairobi; Stern. N. (2007), The Economics of Ecosystems and Biodiversity: Mainstreaming the economics of nature: A Synthesis of the Approach, Conclusions and Recommendations, TEEB; Robins, N. et al. (2010), Green austerity hits the UK, London: HSBC Global Research, Climate Change [10][13]. Reports in the final group analyze how to develop a green economy in specific areas such as OECD (2011), A green growth strategy for food and agriculture-preliminary report, Paris; UNEP (2010), Green economy: Driving the green economy through public finance and fiscal policy reform, Nairobi; J. Stephenson and S. Upton (2010), Strategies for green growth: Framing and issues, OECD [14]-[16]. The publications mentioned above share the view that green economy is necessary for sustainable development and is the most viable economic model for many developing countries despite the high cost of implementation of the necessary strategies. From such publications, 14 models of the green economic development can be sketched. Although each country has 
its own models, the common feature that they share is investment in clean technology, clean production, efficient use of natural resource and green energy.

Researches in Vietnam [17] [18] come to the three vital elements of green economy in Vietnam, which are clean economy (i.e. high intellectual property contained), environment-friendly economy and green development. Bui Quang Tuan [17] has pointed out ten principles of green economy, which are 1) sustainability, 2) existence, 3) healthiness, 4) humanity, 5) fairness, 6) protection, 7) effectiveness, 8) accountability, 9) sufficiency, 10) responsible creativeness. Green economy development in Vietnam is suggested to be done in all three areas including economy, society and environment [19]. This view is repeated in the National Strategy of green growth approved on $25^{\text {th }}$ September 2012. Do Huu Hao [20] stressed the importance of green industry as basis of green economy development in the country. A strong financial status is needed for the development meanwhile national reserves in Vietnam is said to be insufficient, which subtantially affects the result.

\subsection{Hypotheses}

Investment in clean technology, clean production can come from state and/or from enterprises. $97.5 \%$ of enterprises in Vietnam are small and medium sized [21]. They have played an important role in the national economy. However, as noted by Tran Tien Cuong et al. [22], enterprises' technology is basically at the first stage of developing technology which is adopting technology. It is a waste if Vietnam relies the development of green economy on the State and ignores enterprises. Enterprises' renovation of existing technologies into those which are clean and/or renewal are believed to help pushing up the transformation process from brown economy to green one in the country. There are some prominent examples of government's success in directing firms and markets to green economy in reality, especially in histories of many recently emerged economies. During the periods of 1950s and 1960s, both Japanese and South Korean governments decide to lead their technology industries change through importing from other countries. This choice in the 1970s happens while these countries were in the mist of encouraging policies for energy-efficient innovation. Then, shortly afterwards, Japan became one of the leading economies in terms of research and development (R\&D) investment in these industries.

Many studies have proved that financial factors like cash flow, research workers' salaries, etc. much influence on the R\&D expenditures, which is key to renovation [23]-[25]. Finance is always a serious problem for enterprises in Vietnam and is used as a good excuse for them not to invest in renovation [26] and there are many studies both at macro-level and micro-level on how to deal with the situation. Therefore, this paper looks at nonfinancial factors. The following hypotheses are proposed:

Hypothesis 1: Renovation motivation in Vietnamese enterprises is positively associated with non-financial factors including knowledge-based labor force and outside support.

There has been a strong trend of thought running through some studies which consider scientific personnel among dominant motivations for companies to focus on R\&D [27] [28]. Education and vocational training system in Vietnam have not been efficient with the university curricula being very theoretical. Therefore, without knowledge-based labor force, enterprises with sufficient fund for R\&D cannot be motivated with renovation [22] [29]. Besides, for a long time, the linkage among research institutions, enterprises has been so weak, resulting in the fact that enterprises have been isolated in technology renovation [30] and out dated with the recent trend of green renovation. Therefore, it is expected that supports from the Government, research institutions or business partners shall push the Vietnamese enterprises to renovate technology, especially to the green technology [31].

Hypothesis 2: Green renovation in Vietnamese enterprises is positively associated with outside pressure.

Luo \& Bhattacharya [32] has proven that the organization's behavior toward corporate social responsibility including green production stems from various outside pressure, especially from the customers' responsiveness. While there is a high awareness for green growth in Vietnam, micro development in green areas is rather at the beginning stage [33]. Therefore, the study assumes that Vietnamese enterprises' attitude on green renovation shall change in accordance with outside pressures. We aim at testing if the change is positive and what outside pressures are for Vietnamese enterprises.

\section{Research Context}

The research is tested in the context of Vietnam, an economy which is in the transitional period from brown into green. 
Green technologies are primarily used in only six areas: construction, transportation, agriculture, industry, energy and waste treatment. $41 \%$ of the green technologies used in waste treatment are for filtration, clean water supply, and waste collection from production, medical facilities and residential use. Most of the green patents in energy are devoted to the production of electricity using solar and wind energy. R\&D activities in construction, transportation and agriculture are not fully invested despite their important role in the process of greening the economy.

With 31 million motorbikes and more than 1.6 million automobiles in Vietnam, transportation is by far the greatest polluter of the environment. Only $4 \%$ of the green patents were granted in the transportation industry, and those were specifically for intelligent transportation systems, infrastructure quality and new more fuel efficient engines.

Among green technologies, some patents have been granted. Patents granted for green technologies were compared with ordinary technologies in Figure 1.

Green patents account for $2.18 \%$ of total patents granted annually, which is said to be extremely inadequate (see Figure 2). It is evident that there is little incentive to develop green patents.

Green patents in Vietnam are held by 6 groups of patent holders: multi-national organizations (including enterprises, investment funds, NGO), local enterprises, universities, research institutes, Vietnamese and foreigners (see Figure 3). Most green patents are in the hands of multi-national organizations.

It has been noted that green patent exploitation depends on research, development and patent licensing activities from multi-national organizations. Such organizations when implementing technology transfer to Vietnam, assign or license a few green patents only, accounting for $1.8 \%$ of the total [34]. There are no official statistics for environmentally friendly patent exploitation by individual holders. Universities and research institutes should be expected to actively participate in the process of new and green technologies renovation and application. However, their research and development mainly meet the demands of the State and depend on State financing. They hold only 8\% of the green patents as shown in Figure 3. Vietnam Technological Science Institute, Vietnam Social Science Institute, Hanoi National Universities and HCM National Universities are the four larg-

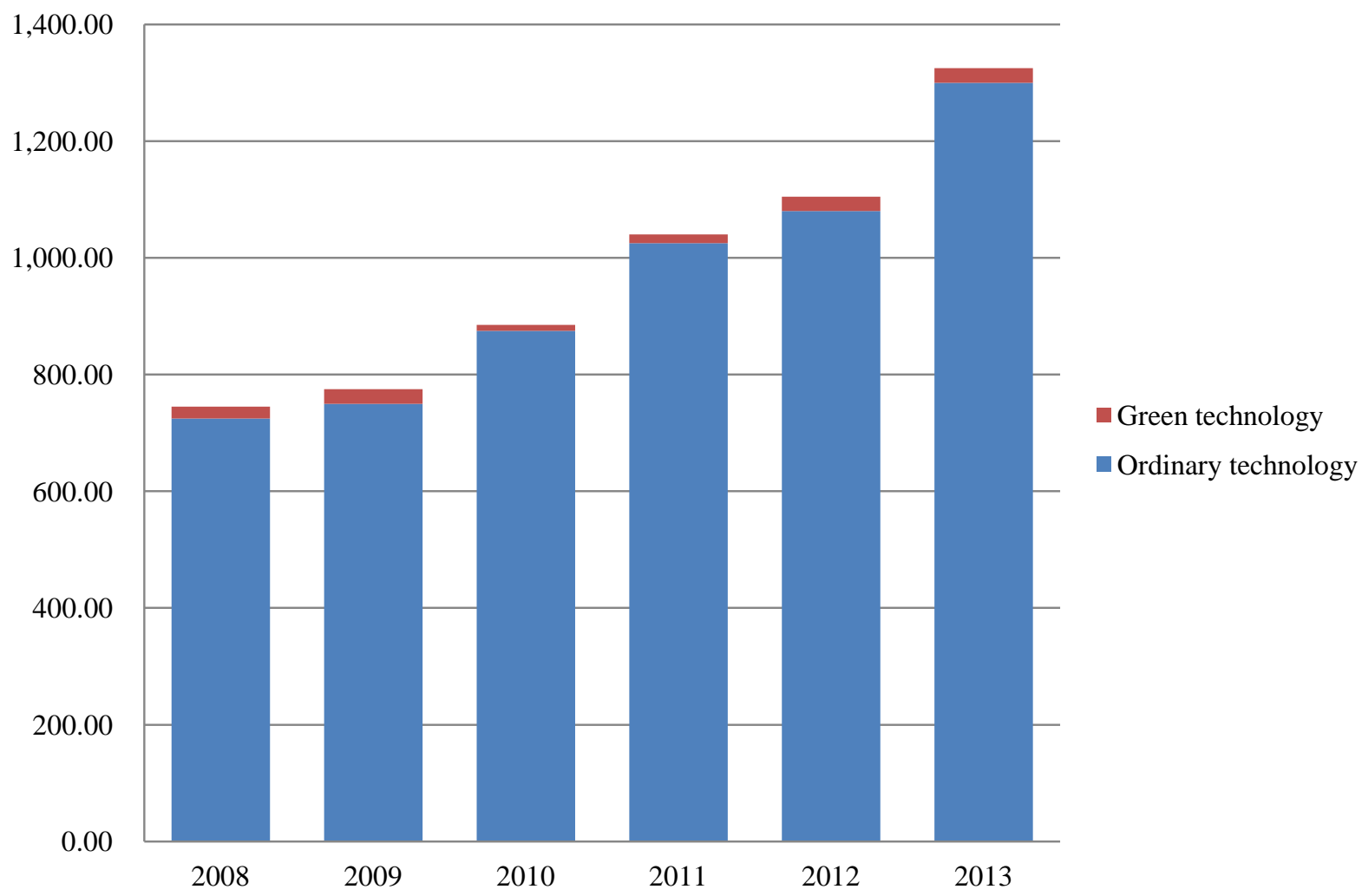

Figure 1. Patents granted in Vietnam in the period of 2008-2013. Source: Data collected from national gazette of Vietnam national office of intellectual property, 2013. 


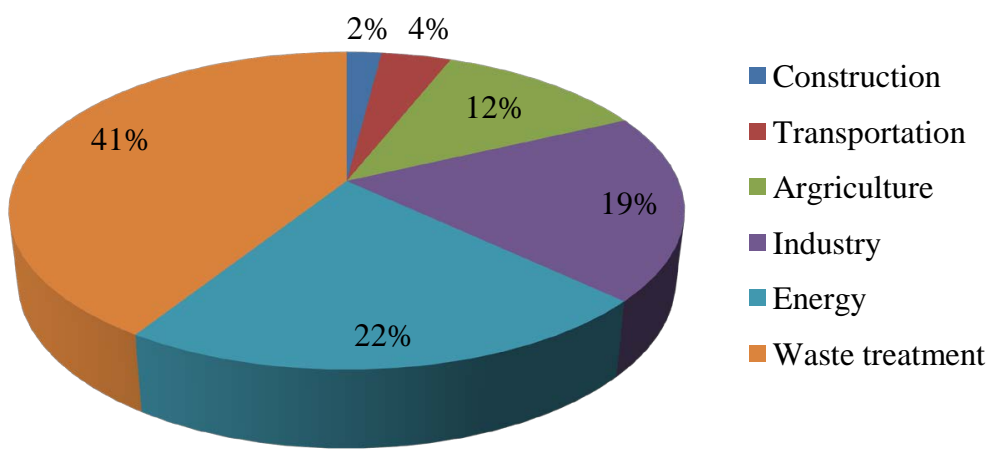

Figure 2. Areas using green technologies in Vietnam from 2008 to Feb 2014. Source: Data collected from National Gazette of Vietnam National Office of Intellectual Property from 2008-Feb 2014.

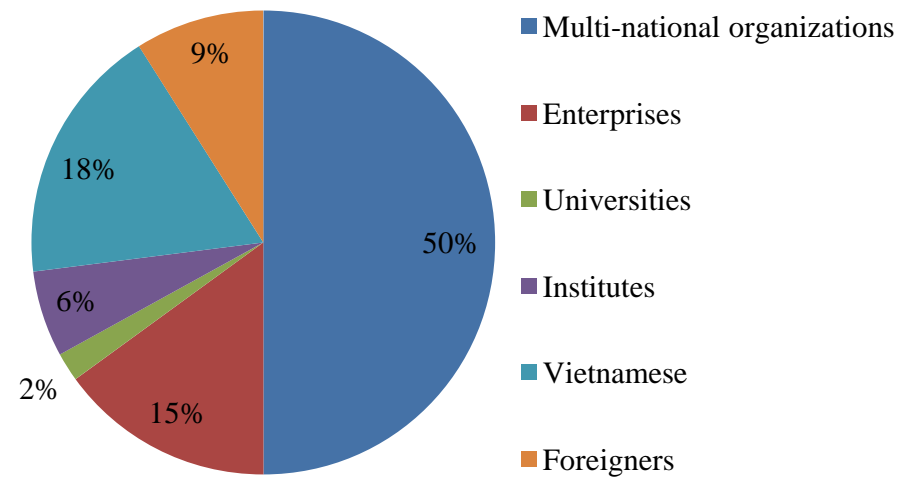

Figure 3. Green patent holder groups in Vietnam. Source: Vietnam National Office of Intellectual Property.

est and most productive universities and research institutes contributing to from $40 \%$ to $50 \%$ of national research [35]. It is admitted that there is a gap between patent development and effective patent exploitation from the said organizations.

\section{Data and Methodologies}

We used data obtained from the survey conducted in 2014 in which we interviewed 450 enterprises in Hanoi, Ho Chi Minh City, Da Nang and Quang Ninh. Hanoi and Ho Chi Minh City are the two biggest centers of economy, education and technology in the North and the South of the country so we assume that enterprises there shall be leaders in green technology renovation. Da Nang and Quang Ninh are situated in the centre and northern centre of Vietnam and are considered to be dynamic in technological areas. Questionnaires were prepared and sent to the said enterprises by postmails and emails.

The number of enterprises in interview was $26.4 \%$ in Ho Chi Minh City, 62.9\% in Hanoi and $10.6 \%$ in Quang Ninh and $10.6 \%$ in Da Nang. $75.3 \%$ of enterprises interviewed situate in urban area; $20.7 \%$ of enterprises interviewed are in industrial zone; $2.7 \%$ are in hi-tech parks and only $1.3 \%$ are in processing zone.

To ensure the accuracy of the information collected, we arranged interviews with management boards or heads of R\&D departments of 20 outstanding enterprises in the fields (see the Appendix for the list of these entrepreneurs).

We arranged meetings with legal scholars and economists in the Central Institute of Economic Management to exchange information and private assessments regarding the restructuring of Vietnam's economy from brown to green.

Besides, the paper used data obtained from the National Office of Intellectual Property to have an overview of green technologies in Vietnam and work out the number of green patents out of the total granted in Vietnam up to 2013 in order to quantize the process of greening the economy in Vietnam. 
First, bivariate relationships among variables were explored via correlation analysis. Then, multiple regression analyses were performed to test proposed hypotheses. The Statistical Package for the Social Sciences (SPSS) was used to support the analyses.

\section{Findings}

\subsection{Hypothesis Testing: Motivation of Renovating Technology in Enterprises}

Renovation motivation in Vietnamese enterprises is positively associated with knowledge-based labor (Table 1).

We use logistic model to valuate factors affecting on the enterprises' decision of technology renovation toward clean and green.

Knowledge-based labor was thought to be important for the enterprises to push the process. We assume:

- Labor: ld

- No skill labor: ld_noskill

- No train labor: ld_notrain

- Basic skill labor : ld_socap

- Intermediate skill labor: ld_trungcap

- Vocational labor : ld_cd

- Graduate labor: $l d \_d h$

As can be seen in the below formula:

$$
\begin{aligned}
l d= & l d_{\text {noskill }}+l d_{\text {notrain }}+l d_{\text {socap }}+l d_{\text {trungcap }}+l d_{\text {tcchuyenghiep }} \\
& +l d_{\text {cdnghe }}+l d_{c d}+l d_{-} d h
\end{aligned}
$$

Variable of labor $(l d)$ is in the below formula:

$$
\begin{aligned}
l d_{e}= & l d_{\text {noskill }}+\left(1+\frac{2}{7}\right) * l d_{\text {notrain }}+\left(1+\frac{3}{7}\right) * l d_{\text {socap }} \\
& +\left(1+\frac{4}{7}\right) * l d_{\text {trungcap }}+\left(1+\frac{5}{7}\right) l d_{c d}+\left(1+\frac{6}{7}\right) * l d_{-} d h
\end{aligned}
$$

Regression of logistic model is used to evaluate the influence of knowledge-based labor on renovation.

$$
L_{i}=\ln \left(\frac{P_{i}}{1-P_{i}}\right)=\alpha_{1} l d_{e}+\alpha_{2} X_{i}+\mu_{i}
$$

As can be seen from the regression, the variable of labor does not have significant impact on the renovation in an enterprise. Same result has shown when $l d_{e}$ is replaced by $l d \_d h, l d \_c d$.

$$
L_{i}=\ln \left(\frac{P_{i}}{1-P_{i}}\right)=\alpha_{i} X_{i}+\mu_{i}
$$

Table 1. Enterprises' motivation to renovate technology.

\begin{tabular}{ccc}
\hline & Motivation & Percentage (\%) \\
\hline 1 & Better quality & 87.26 \\
2 & Lower price & 58.28 \\
3 & Adaptability & 44.59 \\
5 & Lower labor cost & 26.43 \\
6 & Waste treatment & 17.20 \\
7 & Reduction of energy expenditure & $16.26 \%$ \\
\hline
\end{tabular}




\subsubsection{Renovation Motivation Is Positively Associated with Outside Support}

Regression of function (2) provides $X_{\mathrm{i}}$ value 1 provided support from outsiders and 0 with no such support. Outsiders can be authorities, research institutions, business partners, etc.

Regression results from Table 2 have shown that only $\mathrm{X}_{3}$ variable which is the support from outside has effect on renovation motivation.

Table 3 proves that business partners are vital sources to motivate enterprises to renovate their existing technology in general and green technology in particular. The role of research institutes can be seen modest. The support from authorities is weak as well.

\subsubsection{New Determinant Discovered}

Logistic regression of other determinants is also done as below:

- Environmental cost : Q 17

- Environment relating certificates: Q 22 \& 11

- Outside support from business partners: Q 16 \& 3

- SA certificate 8000: Q 22 \& 13

- Export out of revenue: Q 25

Table 2. Logistic regression of technology renovation motivation with support from outside.

\begin{tabular}{|c|c|c|c|c|c|c|}
\hline & & & \multicolumn{4}{|c|}{ Number of obs $=432$} \\
\hline & & & \multicolumn{4}{|c|}{ LR chi2(8) = 15.13} \\
\hline \multicolumn{3}{|c|}{ Logistic regression } & \multicolumn{4}{|c|}{ Prob $>$ chi2 $=0.0567$} \\
\hline & & & \multicolumn{4}{|c|}{ Log likelihood = -245.74589 } \\
\hline & \multirow{3}{*}{$\begin{array}{c}\text { Odds Ratio } \\
1.859729\end{array}$} & \multirow{3}{*}{$\begin{array}{c}\text { Std. Err. } \\
0.4679075\end{array}$} & \multicolumn{4}{|c|}{ Pseudo R2 = 0.0299} \\
\hline \multirow{2}{*}{$\begin{array}{l}\mathrm{L}_{\mathrm{i}} \\
\mathrm{X}_{3}\end{array}$} & & & \multirow{2}{*}{$\begin{array}{c}\mathrm{z} \\
2.47\end{array}$} & \multirow{2}{*}{$\begin{array}{l}\mathrm{P}>|\mathrm{z}| \\
0.014\end{array}$} & \multicolumn{2}{|c|}{ [95\% Conf. Interval] } \\
\hline & & & & & 1.135762 & 3.0451723 \\
\hline $\mathrm{X}_{1}$ & 1.209564 & 0.4095352 & 0.38 & 0.702 & 0.5694337 & 2.309132 \\
\hline $\mathrm{X}_{2}$ & 0.95293 & 0.4403835 & 0.52 & 0.601 & 0.5925427 & 2.469097 \\
\hline $\mathrm{X}_{4}$ & .6243408 & 0.2109306 & -1.39 & 0.163 & 0.3219937 & 1.210587 \\
\hline $\mathrm{X}_{5}$ & 1.612622 & 0.5578401 & 1.38 & 0.167 & 0.8186229 & 3.176737 \\
\hline $\mathrm{X}_{6}$ & 1.101025 & 0.4507991 & 0.24 & 0.814 & 0.4934971 & 2.456459 \\
\hline $\mathrm{X}_{7}$ & 1.085757 & 0.3537507 & 0.25 & 0.801 & 0.5733273 & 2.056188 \\
\hline $\mathrm{X}_{8}$ & 0.9856942 & 0.2931192 & -0.05 & 0.961 & 0.5503228 & 1.765497 \\
\hline
\end{tabular}

Table 3. Outside support for enterprises to renovate technology.

\begin{tabular}{ccc}
\hline Source of support & Support/total enterprises & Support/enterprises having support \\
\hline Local authorities & 21.53 & 31.31 \\
Research management authorities & 20.37 & 29.63 \\
Business partners & 47.92 & 69.70 \\
Non-governmental organizations & 18.06 & 26.26 \\
Research institutes & 18.52 & 26.94 \\
Investment funds & 10.19 & 14.81 \\
Technology conselling organizations & 29.63 & 43.10 \\
Associations & 31.02 & 45.12 \\
Others & 13.6 & 19.87 \\
\hline
\end{tabular}


Table 4 confirms our argument above on significant impact of support from business partners on technology motivation, which shows the ratio of 1.87 in comparison with the others.

Table 4 also reveals a determinant which positively associated with renovation motivation in Vietnamese enterprises, which is pressure from existing environment relating certificates. As can be seen, enterprises holding environment relating certificates have the ratio of 2.4 of technology renovation in comparison with the others.

\subsection{Hypothesis Testing: Green Renovation in Vietnamese Enterprises Is Positively Associated with Outside Pressure}

The survey includes a question on the determinants of the green development for enterprises with the Likert scale from zero-no importance to 5-extremely importance. The result can be seen in the Table 5 .

Table 5 shows that customers' requirements and authorities' requirements are the two outstanding determinants of the green development for enterprises (the mean is more than 3 ). This result is fit with the existing surveys. Only 28\% out of the 9012 production enterprises nationwide are aware of green production, $11 \%$ thereof have applied green production to reduce energy consumption per product unit, and only $18 \%$ have employed competent staff for green production [29]. Moreover, some enterprises hold the opinion that investment in technology generally or in green technologies in particular can only be managed by large enterprises.

Customers in 91 enterprises in our survey have required environment relating certificates but only 39 enterprises can meet such demand.

$56 \%$ of the enterprises admitted that green development has been urgent need for them to improve their competitiveness (the Likert scale is 4 out of 5). The outside pressure for green development on the enterprises has been seen increasing. Around $10.2 \%$ of the enterprises in the sample have certificates relating to green development like certificates of environment, etc meanwhile $30.56 \%$ enterprises have faced with the requirement of such certificates from their customers and $29.4 \%$ enterprises have been asked to show such certificates in order to access foreign markets. Those numbers have shown that Vietnamese enterprises have lost many opportunities to access new markets, new customers.

Table 4. Regression of determinants of technology renovation.

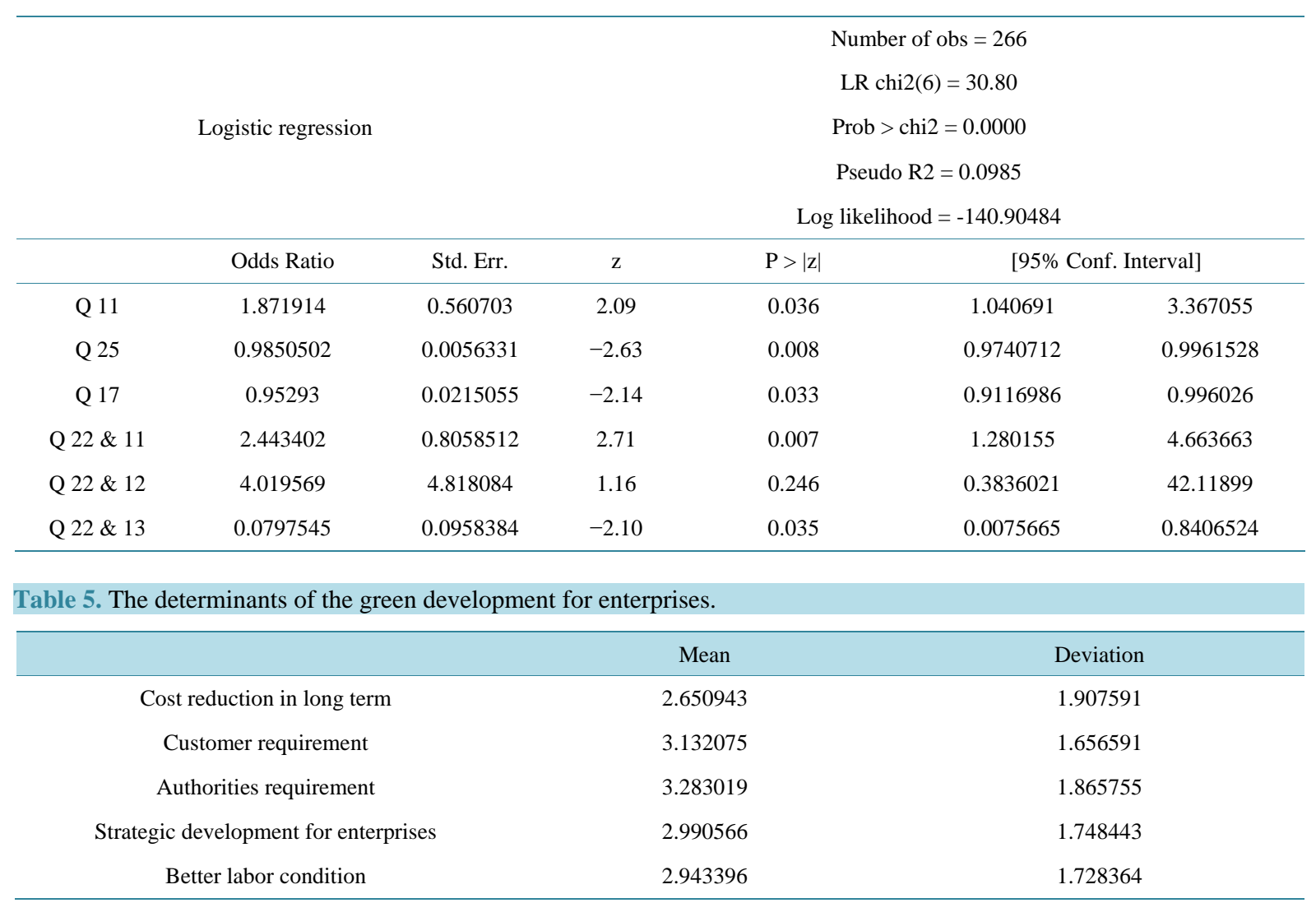




\section{Discussion and Implications of the Research}

This study explores the relationships among renovation motivation in Vietnamese enterprises, knowledge-based labor and outside support. Inconsistent with the existing literature where knowledge-based labor was found to be dominant motivation for companies' renovation, the study shows that such labor force does not have significant impact on the renovation in an enterprise in Vietnam.

It is proven here that there is a strong linkage between renovation and outside supports (authorities, business partners, research institutes). Also, customers' requirements and authorities' regulations are two outstanding determinants to push the renovation toward greening process. Therefore, it is recommended for the government to develop these links and to erase obstacles which weaken such links. The obstacles can be unavailable subsidies for clean electricity, discouraging investment in wind and solar energy [36].

It is found in this study that pressure from existing environment-relating certificates is positively associated with renovation motivation in Vietnamese enterprises. The government should take advantage of such pressure to encourage enterprises to invest resources in the development of green patents and/or to the exploitation thereof in the shortest time as implemented in Japan and the United States [37] [38].

This study has two main limitations. First, it relies on cross-sectional survey; therefore, causal relationships among variables cannot be confirmed. Second, measures of determinants are still based on subjective assessment of managers in the enterprises. Future research could address these weaknesses by including objective measures of determinants and conducting longitudinal studies.

Despite all the limitations, results of this study still advance our knowledge of the relation between the green economy development and enterprises' involvement. The study has provided some important implications for enterprises' managers and for policy makers.

\section{Funding}

This research is funded by Vietnam National Foundation for Science and Technology Development (NAFOSTED) under grant number II4.5-2012.02.

\section{References}

[1] UNIDO (2012) Toward Green Growth through Green Industry Development in Vietnam. http://www.unido.org/fileadmin/user_media_upgrade/Worldwide/Offices/ASIA_and_PACIFIC/vn_Green_Growth_Th rough_Green_Industry_Development_in_VietNam_June2012.pdf

[2] Allen, C. (2012) A Guidebook to the Green Economy, Issue 3: Exploring Green Economy Policies and International Experience with National Strategies. UN Division for Sustainable Development.

[3] Nguyen, T.H., et al. (2010) Preliminary Study on Sustainable Low-Carbon Development towards 2030 in Vietnam. Asia-Pacific Integrated Model Team, GCOE on Human Security Engineering for Asian Megacities-Kyoto University in Corporation with National Institute for Environmental Studies.

[4] Tuan, N.A. (2013) Policies and Solutions for Renewable Energy Development in Vietnam. http://www.ievn.com/tin-tuc/Chinh-sach-va-giai-phap-thuc-day-phat-trien-nang-luong-tai-tao-o-viet-nam-5-1029.aspx

[5] Rogall, H. (2011) Nachhaltige Ökonomie-Ökonomische Theorie und Praxis einer nachhaltigen Entwicklung.

[6] Earthsummit (2012) Principles for the Green Economy: A Collection of Principles for the Green Economy in the Context of Sustainable Development and Poverty Eradication.

[7] OECD (2011) Towards Green Growth: A Summary for Policy Makers. OECD, Paris.

[8] UNEP (2011) Towards a Green Economy: Pathways to Sustainable Development and Poverty Eradication. UNEP, Nairobi.

[9] UN (2012) Working towards a Balanced and Inclusive Green Economy: A United Nations System-Wide Perspective.

[10] UNESCO (2011) From Green Economies to Green Societies. UNESCO, Paris.

[11] UNEP (2010) Green Economy-Developing Countries Success Stories. UNEP, Nairobi.

[12] Stern. N. (2007) The Economics of Ecosystems and Biodiversity: Mainstreaming the Economics of Nature: A Synthesis of the Approach. Conclusions and Recommendations, TEEB.

[13] Robins, N., et al. (2010) Green Austerity Hits the UK. HSBC Global Research, Climate Change, London.

[14] OECD (2011) A Green Growth Strategy for Food and Agriculture-Preliminary Report. OECD, Paris.

[15] UNEP (2010) Green Economy: Driving the Green Economy through Public Finance and Fiscal Policy Reform. UNEP, Nairobi. 
[16] Stephenson, J. and Upton, S. (2010) Strategies for Green Growth: Framing and Issues. OECD.

[17] Tuan, B.Q. (2011) Exploitation and Usage of Green Energy in Vietnam. International Conference Proceeding "Green Growth Strategy in Korea and Implications for Vietnam”, Eastern North of Asia Study Institute.

[18] Thuan, N.Q. and Trung, N.X. (2012) Green Economy in the Renovation of Growth Model and Restructure of Vietnamese Economy in the Coming Period. Workshop "Spring Economic Forum 2012: Vietnam Economy 2012: Aggressive Start-Up for the Restructure of the Economy”, The National Assembly Committee, Danang, 7-8 April 2012.

[19] Hai, N.N., Huy, N.T. and Hien, P.M. (2013) Conditions for Green Economy in Vietnam. Workshop Proceeding “Green Economy Development based on Interlectual Property Exploitation: Problems Raised”, Foreign Trade University, Hanoi, December 2013.

[20] Hao, D.H. (2014) Industrial Suggestion for Environmental and Economical Protection. http://cantho.gov.vn/wps/wcm/connect/sotnmt/sub+site/sitemenu/linhvucquanly/linh+vuc+khoa+hoc+cong+nghe/cong +nghe+xanh-loi+giai+cho+bai+toan+bao+ve+moi+truong+va+kinh+te

[21] Nguyen, H. (2014) Doanh nghiệp nhỏ và vừa Việt Nam: Tăng sức mạnh "bó đũa”. http://www.vietnamplus.vn/doanh-nghiep-nho-va-vua-viet-nam-tang-suc-manh-bo-dua/260411.vnp

[22] Cuong, T.T., Sang, L.X. and Anh, N.K. (2008) Vietnam’ Small and Medium Sized Enterprises Development: Characteristics, Constraints and Policy Recommendations. In: Lim, H., Ed., SME in Asia and Globalization, ERIA Research Project Report 2007-5.

[23] Kuzets, S. (1962) Inventive Activity: Problems of Definition and Measurement. In: National Bureau of Economic Research, The Rate and Direction of Inventive Activity, Princeton University Press, Princeton.

[24] Sanders, B.S. (1962) Some Difficulties in Measuring Inventive Activity. In: National Bureau of Economic Research, The Rate and Direction of Inventive Activity, Princeton University Press, Princeton.

[25] Grabowski, H. (1967) The Determinants and Effects of Industrial Research and Development. Ph.D Dissertation, Princeton University, Princeton.

[26] Bezanson, K. (2000) A Science Technology and Industry Strategy for Vietnam. A Document Prepared as Part of UNDP/UNIDO Project DP/VIE/99/002: Vietnam-Contribution to the Preparation of the Socio-Economic Development Strategy to the Year 2010, UNIDO.

[27] National Science Foundation (1956) Science and Engineering in American Industry. National Science Foundation, Washington DC.

[28] Grabowski, H. (1966) The Determinants and Effects of Industrial Research and Development. Econometric Research Program, Research Memorandum No. 82, Princeton University, Princeton.

[29] Rand, J. and Tarp, F. (2007) Characteristics of the Vietnamese Business Environment: Evidence from a SME Survey in 2005. Component 5- Business Sector Research, Business Sector Program Support, CIEM, DoE, ILSSA.

[30] Ba, L.X., Hao, T.K. and Thang, N.H. (2006) Vietnam's SMEs in the Context of Economic Intergration. Politics Publishing House, Hanoi.

[31] Nguyen, N.Q. and Ngoc, H.T. (2014) Exploitation and Commercialization of Inventions towards Green Economy. Journal of Business and Economics, 5.

[32] Luo, X. and Bhattacharya, C.B. (2006) Corporate Social Responsibility: A Fresh Perspective in Theory and Practice. Journal of Business Ethics, 82, 213-231.

[33] ILO (2011) Skills for Green Jobs: A Global View, Synthesis Report Based on 21 Country Studies. ILO, Geneva.

[34] Noip (2014) National Gazettes 2008. 2009, 2010, 2011, 2012, 2013, Feb 2014.

[35] The Ministry of Science and Technology (2013) Survey on Invention Commercialization Market.

[36] Quat, P.H. (2014) Patent Exploitation Situation. Workshop “Green Economy Development Based on Intellectual Property Exploitation: Arising Problems”, Hanoi, March 2014.

[37] Japan Patent Office (2010) Outline of Accelerated Examination and Accelerated Appeal Examination. http://www.jpo.go.jp/cgi/linke.cgi?url=/torikumi_e/t_torikumi_e/outline_accelerated.htm

[38] United States Patent and Trademark Office (2012) Green Petition Report Summary. 


\section{Appendix}

List of 20 outstanding companies whose managers interviewed:

\begin{tabular}{|c|c|c|}
\hline 1. & Truong Hai Automobile Jsc & 80 Nguyen Van Troi, District 8, Hochiminh City \\
\hline 2. & Asia Logistic Ltd & 215 Nguyen Xi, District 15, Binh Thanh, Hochiminh City \\
\hline 3. & VFO Logistic Ltd & $\begin{array}{l}\text { 248/33/1 Nguyen Thai Binh, District 12, } \\
\text { Phu Nhuan, Hochiminh City }\end{array}$ \\
\hline 4. & Viet My Contruction Material Technology jsc & $\begin{array}{l}\text { A1101, Satra Eximland Building, District 12, } \\
\text { Phu Nhuan, Hochiminh City }\end{array}$ \\
\hline 5. & Phu Lam Plastic Jsc & Lô 109 Kenamata, Long Binh, Bien Hoa, Dong Nai \\
\hline 6. & Fant Asia Technology Pte. Ltd & 222/56 Bui Dinh Quy. Binh Thanh, Hochiminh City \\
\hline 7. & Hong Loan Contruction and Transportation Ltd & 99E Cong Hoa, Tan Binh, Hochiminh City \\
\hline 8. & Bao Viet Health Equipment Jsc & 115/12 Le Trong Tan, Son Ky, Tan Phu, Hochiminh City \\
\hline 9. & Quang Ngai Investment and Construction Jsc & 112 Phan Dinh Phung, Quang Ngai \\
\hline 10. & ITEE Environment and Material Technology Ltd & 125/77 304 Road Binh Thanh, Hochiminh City \\
\hline 11. & Nam Son Investment and Production Jsc & 22 X6-Group 7 Thach Ban, Long Bien, Hanoi \\
\hline \multirow[t]{2}{*}{12.} & Tung Lam Construction and Timber Jsc & 1081 Hong Ha, Hoan Kiem, Hanoi \\
\hline & Thinh Phat Production and Construction Ltd & Kenh Cau Dong Than, Hung Yen \\
\hline 13. & Dairy Goat Jsc & 40 Cat Linh, Dong Da, Hanoi \\
\hline 14. & MixDigital Jsc & 1401, A Building, Hathanh Plaza, Dong Da, Hanoi \\
\hline 15. & Hoang Phuong Chemicals and Health Equipment Ltd & 93/7 Vuong Thua Vu, Thanh Xuan, Hanoi \\
\hline 16. & VS C-Posco Steel Ltd & Quan Toan, Hong Bang, Hai phong \\
\hline 17. & Mediplantex Jsc & 33 Giai Phong, Thanh Xuan, Hanoi \\
\hline 18. & Duc Viet Food Jsc & SeaProdex, 20 Lang Ha, Dong Da, Hanoi \\
\hline 19. & Vinacomin Electrical Equipment Jsc & 822 Tran Phuc Road, Cam Thach, Cam Pha, Quang Ninh \\
\hline
\end{tabular}

